\title{
ASH COMPOSITION AND DEPOSITION TENDENCIES OF SELECTED BIOMASS TYPES
}

\author{
Grzegorz ZAJĄC, Joanna SZYSZLAK-BARGLOWICZ, Agnieszka DUDZIAK, \\ Andrzej KURANC, Jacek WASILEWSKI \\ University of Life Sciences in Lublin, POLAND \\ E-mail of corresponding author: grzegorz.zajac@up.lublin.pl
}

Keywords: Sustainable development, Biomass, Ash, Slagging, Fouling

\begin{abstract}
Replacement of fossil fuel with renewables including biomass is one of the ways to ensure sustainable development. Biomass incineration is most frequently used energy conversion technology. Notwithstanding that ash arising from the biomass incineration process may cause problems with boiler furnace ash slagging and fouling. This paper presents the resulting figures for computation of indicators that may be used for anticipating ash reaction in respect of selected biomass type. The analysis of those indicators has proven that the Sunflower husks is characteristic of the highest risk of ash slagging and fouling, and Miscanthus Giganteus and wheat straw are characteristic of the lowest risk of ash slagging and fouling.
\end{abstract}

\section{INTRODUCTION}

The idea of the sustainable development is the major drive force in paving the way towards the sustainable economic growth alongside the long-lasting access to natural resources and preservation of natural environment as a value (Wasiak, 2017). Replacement of fossil fuel with renewables, mainly agriculture-derived renewables, is commonly considered to be one of the ways to ensure sustainable development. Nowadays biofuel has not only aroused theoretical and scientific interest but has also developed to occupy a considerable fuel market share to represent the strategically significant sustainable energy source (Wasiak, 2017).

Out of all the types of biofuel that are commonly used, biomass is currently taking on significance as it follows charcoal and crude oil as far as the largest source of primary energy is concerned in the world. Biomass incineration is the most developed technology of conversion of biomass into energy, and biomass incineration in small power boilers is one of the ways to use it for energy purposes (Mirowski, 2016). Biomass may be incinerated as it is or in the processed form of briquettes or pellets but compact fuel gains more and more popularity due to its advantageous usability (Obidziński, 2014; Szyszlak-Barglowicz and Zajac, 2015; Szyszlak-Barglowicz et al., 2015). Notwithstanding the benefits that arise from biomass incineration, organisation of that process is still a huge challenge (Zajac et al., 2017). There are numerous reasons for that and among them the significant issue arises from creation of ash that is the product of incineration when the incineration is still a continuing process and when it is completed (Niu et al., 2016). Reaction of ash derived from the biomass incineration affects operations of the boiler. Although the ash content in biomass is much lower than in charcoal, its source of origin and chemical composition affect the boiler inter alia causing slag and ash to deposit on the boiler furnace to a greater extent, faster wear-andtear of metal boiler pieces in effect of corrosion. Those problems may cause operating expenses to rise and equipment efficiency and accessibility to diminish (Vamvuka and Zografos, 2004).

Ash deposition-related problems depend on both the boiler construction design and operational conditions, as well as fuel composition (Ma et al., 2007). Biomass source of 
origin has a considerable impact upon ash properties. Ash reaction in the boiler furnace may be assessed by means of parameters defined in literature (Bryers, 1996; Vamvuka and Zografos, 2004; Pronobis, 2005; Viana et al., 2012; Garcia-Maraver et al., 2017).

The aim of the study has been to define chemical composition of ash derived from varied types of biomass and on that basis to assess ash slagging and fouling of the boiler furnaces, making use of indicators available in related scientific literature.

\section{MATERIAL AND METHODS}

For the purpose of the study 9 most popular biomass sources used for energy purposes in Poland have been analysed. This has been biomass derived from wood industry waste in the form of pine wood chips, lignocellulosic biomass in the form of oak timber, energy crops: willow coppice, poplar, Sida Hermaphrodita, Miscanthus Giganteus, agricultural waste: wheat straw and rape straw and food production waste in the form of sunflower husk.

The study objects had been prepared in compliance with PN-EN 14778 standard. Primary biomass composition was defined by means of CHNS analyser made by LECO. Ash content was defined in compliance with PN-EN ISO 18122 standard. Measurements were made by means of LECO TGA 701 instrument, according to the thermogravimetric method. Incineration heat was defined by means of working probes. It was performed in conformity with PN-ISO 1928 standard, and LECO AC600 calorimeter was used for measuring purposes. Ash content was analysed by means of Thermo iCAP 6500 Duo ICP plasma spectrometer using ASCRM -010 as the reference substance. In the case of ash the following was defined: silica as $\mathrm{SiO}_{2}$, iron as $\mathrm{Fe}_{2} \mathrm{O}_{3}$, aluminium as $\mathrm{Al}_{2} \mathrm{O}_{3}$, calcium as $\mathrm{CaO}$, magnesium as $\mathrm{MgO}$, phosphorus as $\mathrm{P}_{2} \mathrm{O}_{5}$, sodium as $\mathrm{Na}_{2} \mathrm{O}$, potassium as $\mathrm{K}_{2} \mathrm{O}$.

Based on the ash chemical composition expressed as major oxides, the ultimate and proximate analysis was conducted, and the ash slagging and pollution indices were computed according to the correlations referred to in related papers (Bryers, 1996; Vamvuka and Zografos, 2004; Pronobis, 2005; Viana et al., 2012; Garcia-Maraver et al., 2017):

\section{Base to Acid index (B/A)}

The ratio of basic to acidic compounds is considered to be an index for predicting ash deposit inclination. The Base to Acid index was calculated according to the following equation formula:

$$
\frac{\mathrm{B}}{\mathrm{A}}=\frac{\mathrm{Fe}_{2} \mathrm{O}_{3}+\mathrm{CaO}+\mathrm{MgO}+\mathrm{Na}_{2} \mathrm{O}+\mathrm{K}_{2} \mathrm{O}}{\mathrm{SiO}_{2}+\mathrm{Al}_{2} \mathrm{O}_{3}}
$$

The lower the B/A value was, the higher the ash melting and flowing temperature was, and thus the risk of ash slagging was lower.

If the $\mathrm{B} / \mathrm{A}<0,15$ the danger of slagging decreases, if $\mathrm{B} / \mathrm{A}$ temperature exceeds $1600^{\circ} \mathrm{C}$. Since: it is plausible to anticipate that slagging tendency if the $\mathrm{B} / \mathrm{A}<0.75$ (Pronobis, 2005).

\section{Slagging (Babcock) index (Rs)}

The Rs index is based on the B/A ratio, but it considers the sulphur content [16] because of previous observations referring to sulphur-containing biomasses with the formation 
of deposits enriched in alkali sulphates, which are unstable at typical combustion temperatures. The Rs Index was computed according to the following equation formula:

$$
R_{s}=\left(\frac{B}{A}\right) S^{d}
$$

where:

$S^{d}$ - is the percentage of $S$ in dry fuel

If Rs $<0.6$, low slagging inclination; if $0.6<\mathrm{Rs}<2$, medium trend; if $2.0<\mathrm{Rs}<$ 2.6, high trend; if Rs $>2.6$, very high trend (Pronobis, 2005).

\section{Alkali Index (AI)}

The Alkali Index expresses the quantity of alkali oxides in the fuel per unit of fuel energy. AI was calculated according to the following equation formula:

$$
\mathrm{AI}=\frac{\left(\mathrm{K}_{2} \mathrm{O}+\mathrm{Na}_{2} \mathrm{O}\right) \mathrm{A}}{\mathrm{HHV}}
$$

where:

A - ash concentration obtained in temperature of $550^{\circ} \mathrm{C}$

$\mathrm{HHV}$ - is the Higher Heating value $\left(\mathrm{MJ} \cdot \mathrm{kg}^{-1}\right)$

When $\mathrm{AI}>0.17 \mathrm{~kg} / \mathrm{MJ}$ fouling or slagging is probable, if $\mathrm{AI}<0.34$ fouling or slagging is virtually certain to occur.

\section{Sintering index (SI)}

The Sintering index (SI) [18] was calculated according to the following equation formula:

$$
\mathrm{SI}=\frac{\mathrm{CaO}+\mathrm{MgO}}{\mathrm{Na}_{2} \mathrm{O}+\mathrm{K}_{2} \mathrm{O}}
$$

If SI> 2 no slagging should be expected, If $\mathrm{SI}<2$ the slagging risk should be high.

\section{Iron to calcium ratio}

The IC indicator, being the ratio of iron oxide to calcium oxide, was computed according to the following equation formula:

$$
\mathrm{IC}=\frac{\mathrm{Fe}_{2} \mathrm{O}_{3}}{\mathrm{CaO}}
$$

If IC $<0.3$ or IC $>3.0$, pollution susceptibility is low and if $0.3<$ IC $<3.0$, it is high.

\section{Slag viscosity index $(\mathrm{Sr})$}

This index calculates the percentage of silica in the basic compounds of the ash, excluding the alkali compounds. The $\mathrm{Sr}$ was calculated according to the following equation:

$$
\mathrm{Sr}=\frac{\mathrm{SiO}_{2} \cdot 100}{\mathrm{SiO}_{2}+\mathrm{Fe}_{2} \mathrm{O}_{3}+\mathrm{CaO}+\mathrm{MgO}}
$$

High $\mathrm{Sr}$ values correspond to high viscosity, and hence to low slagging tendency. If $\mathrm{SR}>72$, it indicates low slagging inclination, if 72>SR $>65$ medium, $\mathrm{SR}<65$ high. 


\section{RESULTS AND DISCUSSION}

After having analysed the resulting figures of the study of biomass and chemical composition of ash obtained in the temperature of $550^{\circ} \mathrm{C}$, it was concluded that the prevalent feature of lignocellulosic ash was high calcium content. Straw ash mainly contained silica and potassium. Out of the energy crops under consideration, Sida Hermaphrodita ash contained substantial quantity of calcium and potassium alongside small content of silica whereas Miscanthus Giganteus ash contained most of potassium and silica. The Sunflower husks ash contained most of potassium - the highest content amongst the biomass under consideration. All the types of biomass were characteristic of low sulphur content. Ash content in fuel such as biomass is a fairly complex issue. Ash quantity is pre-conditioned by the content of organic matter, inorganic matter, and possible biomass pollution. Besides, incineration temperature also has the impact upon the quantity of obtained ash. It also bears noting that the very information on the quantity of ash is not complete if it is not interpreted in relation to the origin of biomass composition. Ash content in the biomass under consideration ranged from 0,31 to 9.98\%. Lower values were obtained for the lignocellulosic biomass and the highest - for straw and sun flower shell.

The indices computed according to the equation formulae 1-6 have been presented in the Table 1. In relation to the values corresponding to the ash slagging and fouling, the resulting figures were marked as extremely high (E), high $(\mathrm{H})$, medium $(\mathrm{M})$ and low (L), in conformity with the study methodology.

Table 1. Ash content in biomass for boiler furnace.

\begin{tabular}{|c|c|c|c|c|c|c|c|c|c|c|c|c|}
\hline & \multicolumn{2}{|c|}{$\mathrm{B} / \mathrm{A}$} & \multicolumn{2}{|c|}{ Rs } & \multicolumn{2}{|c|}{ AI } & \multicolumn{2}{|c|}{ SI } & \multicolumn{2}{|c|}{ IC } & \multicolumn{2}{|c|}{$\mathrm{Sr}$} \\
\hline & value & risk & value & risk & value & risk & value & risk & value & risk & value & risk \\
\hline $\begin{array}{l}\text { Pine (wood } \\
\text { chips) }\end{array}$ & 6.24 & $\mathrm{E}$ & 0.06 & $\mathrm{~L}$ & 0.42 & $\mathrm{M}$ & 4.29 & $\mathrm{~L}$ & 0.05 & $\mathrm{~L}$ & 13.68 & $\mathrm{H}$ \\
\hline Oak & 3.67 & $\mathrm{E}$ & 0.04 & $\mathrm{~L}$ & 0.25 & $\mathrm{M}$ & 2.86 & $\mathrm{~L}$ & 0.03 & $\mathrm{~L}$ & 21.12 & $\mathrm{H}$ \\
\hline Poplar & 4.19 & $\mathrm{E}$ & 0.21 & $\mathrm{~L}$ & 1.04 & $\mathrm{M}$ & 2.64 & $\mathrm{~L}$ & 0.01 & $\mathrm{~L}$ & 23.71 & $\mathrm{H}$ \\
\hline $\begin{array}{l}\text { Willow } \\
\text { Coppice }\end{array}$ & 2.51 & $\mathrm{E}$ & 0.05 & $\mathrm{~L}$ & 1.56 & M & 2.63 & $\mathrm{~L}$ & 0.01 & $\mathrm{~L}$ & 34.82 & $\mathrm{H}$ \\
\hline $\begin{array}{l}\text { Sida } \\
\text { Hermaphro } \\
\text { dita }\end{array}$ & 6.48 & $\mathrm{E}$ & 0.37 & $\mathrm{~L}$ & 4.68 & $\mathrm{~L}$ & 1.29 & $\mathrm{H}$ & 0.02 & $\mathrm{~L}$ & 18.72 & $\mathrm{H}$ \\
\hline $\begin{array}{l}\text { Miscanthus } \\
\text { Giganteus }\end{array}$ & 0.80 & M & 0.01 & $\mathrm{~L}$ & 5.86 & $\mathrm{~L}$ & 0.50 & $\mathrm{E}$ & 0.10 & $\mathrm{~L}$ & 77.98 & $\mathrm{~L}$ \\
\hline $\begin{array}{l}\text { Wheat } \\
\text { Straw }\end{array}$ & 0.60 & M & 0.02 & $\mathrm{~L}$ & 8.11 & $\mathrm{~L}$ & 0.49 & $\mathrm{E}$ & 0.13 & $\mathrm{~L}$ & 82.30 & $\mathrm{~L}$ \\
\hline Rape Straw & 1.41 & $\mathrm{H}$ & 0.11 & $\mathrm{~L}$ & 14.33 & $\mathrm{~L}$ & 0.43 & $\mathrm{E}$ & 0.13 & $\mathrm{~L}$ & 66.86 & $\mathrm{M}$ \\
\hline $\begin{array}{l}\text { Sunflower } \\
\text { husks }\end{array}$ & 15.53 & $\mathrm{E}$ & 2.58 & $\mathrm{H}$ & 25.12 & $\mathrm{~L}$ & 0.41 & $\mathrm{E}$ & 0.23 & $\mathrm{~L}$ & 16.46 & $\mathrm{H}$ \\
\hline
\end{tabular}

Taking into consideration exclusively the $\mathrm{B} / \mathrm{A}$ indicator, it is plausible to state that nearly every type of the biomass under consideration has been characteristic of high or 
very high ash slagging inclination, except for Miscanthus Giganteus and wheat straw. However, due to the low Sulphur content in the biomass under consideration, Rs index is indicative of low ash fouling. The remaining indicators actually are derivatives of various values of respective components of biomass ash. Lignocellulosic biomass has had higher values of AI and Sr indicators whereas energy crops and straw biomass has had higher values of SI indicator and lower values of AI and Sr indicators. This may be explained by the lower value of alkali content ( $\mathrm{K}$ and $\mathrm{Na}$ ) in the lignocellulosic ash.

Given the analysis of the resulting indicators, it has been concluded that the Sunflower husks biomass is characteristic of the highest risk of ash slagging and fouling, and wheat straw and Miscanthus Giganteus biomass is characteristic of the lowest risk of ash slagging and fouling.

However, it bears noting that the designated indicators do not provide fully credible information on the growth rate of deposited formation in the boilers because they exclusively depend on the biomass chemical composition. Furthermore, even in relation to the specific biomass, soil conditions, harvesting periods and various biomass parts may have an impact upon diversified quantity and ash chemical composition (Niu et al., 2016).

\section{CONCLUSIONS}

Chemical composition of ash is one of the major problems connected with the use of biomass for energy purposes. Main problematic issues are represented by ash components, namely alkali metals $(\mathrm{K}, \mathrm{Na})$, alkaline earth metals $(\mathrm{Ca}, \mathrm{Mg})$ and Silicon, Chlorine and Sulphur. The resulting ash pollution indicators for boiler furnaces in the case of the types of biomass under consideration do not clearly indicate ash slagging or fouling tendencies but suggest the risk of technical problems during boiler operations. The Sunflower husk is the exception because its indicators clearly indicate that its incineration may cause considerable problems. With regard to the above, further research is needed in the context of varied incineration technologies and boiler operational conditions, taking into consideration variables of various types of the biomass.

Taking also into consideration that the ash chemical composition also results from the fertilisation manner, cultivation procedures or harvesting period, research must be conducted to avoid accumulation of hazardous elements during cultivation.

\section{REFERENCES}

Bryers, R. W. (1996). Fireside slagging, fouling, and high-temperature corrosion of heat-transfer surface due to impurities in steam-raising fuels. Prog. Energy Combust. Sci. 22 (1), 29-120.

Garcia-Maraver, A., Mata-Sanchez, J., Carpio, M., Perez-Jimenez, J. A. (2017). Critical review of predictive coefficients for biomass ash deposition tendency. J. Energy Inst. 90 (2), 214-228.

Ma, Z., Iman, F., Lu, P., Sears, R., Kong, L., Rokanuzzaman, A. S., McCollor, D. P., Benson, S. A. (2007). A comprehensive slagging and fouling prediction tool for coal-fired boilers and its validation/application. Impacts Fuel Qual. Power Prod. 88 (11), 1035-1043.

Mirowski, T. (2016). Wykorzystanie biomasy na cele grzewcze a ograniczenie emisji zanieczyszczeń powietrza z sektora komunalno-bytowego. Rocz. Ochr. Śr. 18, 466-477.

Niu, Y., Tan, H., Hui, S. 'en. (2016). Ash-related issues during biomass combustion: Alkali-induced slagging, silicate melt-induced slagging (ash fusion), agglomeration, corrosion, ash utilization, and related countermeasures. Prog. Energy Combust. Sci. 52, 1-61. 
Obidziński, S. (2014). Pelletization of biomass waste with potato pulp content. Int. Agrophysics 28 (1), 85-91.

Pronobis, M. (2005). Evaluation of the influence of biomass co-combustion on boiler furnace slagging by means of fusibility correlations. Biomass Bioenergy 28 (4), 375-383.

Szyszlak-Barglowicz, J., Zajac, G., Słowik, T. (2015). Hydrocarbon Emissions during Biomass Combustion. Pol. J. Environ. Stud. 24 (3), 1349-1354.

Szyszlak-Barglowicz, J., Zajac, G. (2015). Distribution of heavy metals in waste streams during combustion of Sida hermaphrodita (L.) Rusby biomass. Przemysl Chem. 94 (10), 1723-1727.

Vamvuka, D., Zografos, D. (2004). Predicting the behaviour of ash from agricultural wastes during combustion. Fuel 83 (14-15), 2051-2057.

Viana, H., Vega-Nieva, D. J., Ortiz Torres, L., Lousada, J., Aranha, J. (2012). Fuel characterization and biomass combustion properties of selected native woody shrub species from central Portugal and NW Spain. Spec. Sect. ACS Clean Coal 102, 737-745.

Wasiak, A. L. (2017). Effect of Biofuel Production on Sustainability of Agriculture. 7th Int. Conf. Eng. Proj. Prod. Manag. 182, 739-746.

Zajac, G., Szyszlak-Barglowicz, J., Slowik, T., Wasilewski, J., Kuranc, A. (2017). Emission characteristics of biomass combustion in a domestic heating boiler fed with wood and Virginia Mallow pellets. Fresenius Environ. Bull. 26 (7), 4663-4670. 